\title{
Divine Sovereignty in the Book of Apocalypse
}

\author{
Dominic Obielosi \\ http://dx.doi./org/10.4314/ujah.v19i1.1
}

\section{Abstract}

Isa 40,1 is a straight call to consolation by God. It was a call that enlivened a rather shattered hope following the lengthy years of exile. The author of the book of Apocalypse like the Deutero-Isaiah has a direct message for his audience. The sadness and despair, the devastated hope coupled with the rushing and entangled thoughts over the persecutions are only preludes to the victory by those who would remain faithful until the end. The Christians are in no position to fight any of their enemies. Unlike the Essenes who were given a War Manual, Christians have no role to play in the terminal and determinant war with Satan. The Christian has the choice of renouncing Christ or suffering martyrdom. The author is aware that without strong conviction that Jesus is king, it would be impossible for the believers to endure such suffering. To elicit such immutable conviction, the author like other apocalyptic pushed home his message through graphic images and symbols. He is sure that the Christians will eventually become victorious just as Christ. They only have to remain patient and faithful. Theirs is better classified as joy in the midst of suffering. This paper studies Revelation as a book of consolation and hope that posits God as a Sovereign God. It sets out to explore how the author of Revelation carefully drives home his message. It is consolatory in as much it elicits hope in the life of a rather shattered group because of persecution. It is a book of hope because it convinces all believers that persecution and martyrdom are all temporal challenges. God 
purposely allowed them to test them. He will eventually prove himself a Sovereign God.

Key words: Revelation, Apocalypse, Persecution, Imageries, Victorious, Sovereignty.

\section{Introduction}

The book of Revelation is also called the book of Apocalypse. It remains one of the most puzzling books of the New Testament. For some, the book of Revelation is a genuine apostolic representation of the end of history. For others, it is a valuable monument from a historical crisis in the history of Christianity. Still few consider it a weakly Christianized Judaism (Kümmel 1995). It is a book of revelation in as much as the author claims to have received revelations from God concerning what is to take place (Apoc 1,1) though Hemer (1989) has reservations regarding problems raised by Rev 1 .

It is an apocalypse because with its exotic imageries it belongs to a type of literature called apocalyptic (Burkett 2002). It is a book that is both spiritual and a critique of the state. As a spiritual book, it addresses believers and encourages resilience and faithfulness in the face of adversity and crises. It gives them assurance of hope. It wants them to believe that there cannot be a crown unless there is first a cross. It posits their sufferings and persecutions as preludes to their glory which will come with the kingdom of God. It is written at the end of the first century and tackles the problem of the Roman persecution of Christianity. With Christianity still illegal in the Roman Empire, there was no end of conflict in sight despite periods of respite between aggressive persecutions. The author gives a forecast of more stormy weather 
before the skies would clear. He expected an imminent parousia and so encouraged the Church experiencing persecution by depicting in a vision the overthrow of Rome and the return of Jesus to establish the kingdom of God (Marxsen 1976). The author paints his thoughts with all important ecstatic imaginative language. It is not a language laddened with rigorous logic but of religious inspiration. The exotic imageries convey the awesomeness of God. The reader arrested by the imageries adopted sees himself removed from the world of daily troubles and historical despair and placed before the throne of God. The reader captivated by thoughts only imagines that at last God is bringing history to its fulfillment.

The book of Apocalypse though written for Christians, is not devoid of influence by Hebrew prophecy just like other apocalyptic books. Many of its images and symbols have long history in Judaism and in surrounding religious cultures. Its emphasis on the immortality of the individual is in line with Hellenistic consciousness. Its adoption of the figure of Satan with a host of demonic assistants coupled with torment for the unrighteous is an offshoot of later apocalypses and Persian Zoroastrianism. Generally, the book is a combination of disappointment with the present (Apoc 1,9;2,10; 7,14) and a continuing hope for the Rule and Sovereignty of God. The author presents the woes suffered by believers as precedents to the end of the age and prelude to God's final victory in which crying and pain will be no more (Apoc 21,4). By declaring an end to oppression he declares the beginning of freedom. In proclaiming the end of human injustice, he proclaims the justice of the Rule and Sovereignty of God. He writes to instil hope in a people who felt marginalized and oppressed. He made efficient use of symbols to communicate his message. For scholars the symbols could be 
interpreted as steno-symbols, that is, standing for something outside the text (Minear 1968). Religiously, they can also function as a symbol of oppressive, God-denying power in any time or place. The visionary looks forward to the ultimate healing of the nations ( $\operatorname{Rev} 22,2)$. The reverse side of the judgment is that of hope, joy and reconciliation. Fiorenza (1981) rightly notes that the strength of Revelation's language and images is not necessarily in theological argumentation or historical information but in their evocative power inviting imaginative participation. The symbols elicit emotions, feelings and convictions that cannot be fully conceptualized. Apocalypse has mythopoetic language akin to poetry and drama.

Apart from evoking emotions, the visionary also deals with cognitive dissonance by inducing "catharsis" or cleansing of emotions and so enables his readers to express and ultimately manage their fear of Roman power and resentment of Roman wealth (Collins 1984). He also by imagining a heavenly reality in which the crucified Jesus is already enthroned and by announcing an already determined future in which the forces of oppression are overcome he tries to convince his audience that what ought to be is. He lets them participate imaginatively in the eschatological peace in the here and now. He does not depict Christians as combating Rome or Satan, but he presents Christ and God as defeating and judging these forces. He constantly transfers his aggressive feelings to other subjects and to eschatological future. Notable also is his introduction of the strategy of internalization in which he encourages his audience to embrace a life of asceticism and martyrdom in relation to wealth, sexuality and participation in the general future. In essence therefore, the author of the book of Apocalypse recognizes the heart-rending situation of persecution facing the Christians. Obviously, many might be scandalized into 
losing hope. The author is consistent in his conviction that all hope is not lost. Cataclysms would be on the increase. More sufferings would still come. Believers are encouraged to embrace all with the hope that the time is at hand for God to overthrow the enemy, establish peace and his divine sovereignty.

This paper recognizes the existence of many apocalyptic books like Daniel, 1Enoch, 4 Ezra, Zechariah, etc but limits its scope to a primary concern as to how the book of Apocalypse demonstrates the reality of divine sovereignty even in the face of apparent hopelessness. The paper sets out to look at the meaning, types and features of Apocalypse. It studies the social setting of the book and sets out to posit the author's purpose. A synopsis of the entire book of Apocalypse is given in comparison with Jewish Apocalypse. A special space is given to a thorough study of the exposition of divine sovereignty in the Apocalypse followed by evaluation and conclusion.

\section{The Book of Revelation as an Apocalypse}

Burkett (2002) defines apocalypse as a literally genre in which an individual receives a revelation or "unveiling" of the normally invisible spiritual world. In this sense, apocalypse has two parts: the physical and the spiritual. The former includes events perceived by normal senses. The spiritual includes God, angels, demons, heaven or hell some truth of which is revealed to the visionary. Most apocalyptic books portend to reveal what would happen at the "end" either of an individual or the world age. The book of Revelation is of the latter. It teaches a cosmic apocalyptic eschatology which looks out for the end of the present world order; establishment of a new and better world order; all brought about by divine intervention and in an imminent future. An apocalypse could be otherworld journey or an historical review. The book of 
Revelation incorporates both. Rohr and Martos (1988) underscores apocalypse to be a revelation of something which has been hidden and which the author describes in a series of dramatic and powerful images. It is a narrative in which other worldly being mediates a revelation to a human recipient (Collins, 1987).

Apocalyptic works have some basic features. The book of Revelation has most of these features. An apocalyptic book is so called firstly because a seer receives a revelation. The revelation comes by various means. It can come by a vision or dream (Rev $1,10.12)$; an otherworldly journey $(\operatorname{Rev} 4,1)$ and instruction from a heavenly being $(\operatorname{Rev} 17,1)$. The vision often appears in symbols. Perrin (1974) observes that apocalyptic works make extensive use of symbols. Rev. 12 is an example. There is also a feeling of determinism. The seer is sure that he is talking of something that must take place (Rev. 1,1). There is generally an expectation of imminent end. The author of the book of Revelation expects Jesus to come soon (Rev. 3,11; 22,7; 12,20; 22,6). The pseudonymous nature of the work also marks it out as an apocalyptic. Most apocalyptic works are written and attributed to famous persons. The book of Revelation is not an exception.

Generally, apocalyptic works free one to be aware of and to deal with unhealthy situations without having to be reliant on results which are intrinsic to the world. They offer the oppressed an archaic, strange, symbolic world which makes possible the developing of identity under persecution and threat of death. Dormeyer (1998) describes the works as resistance literature of the Masses (cf. also Vielhauer, 1975; Derrida, 1985; and Treu, 1989). Compared with other apocalyptic works, the book of Revelation shares a lot in common. All biblical apocalyptic works go back to depressing times in Jewish history. The Old Testament apocalypticism arose from the depressing times of the exile, 
around 538 BCE. The New Testament apocalypticism is not unconnected with the problems of the persecutions. Apart from their rising during periods of depression, it is very obvious that both had Greek influence. The Greek literature such as the myth of the four empires of Hesiod is also familiar with apocalyptic ideas. According to Von Rad (1982), postexilic wisdom took up old oriental, Persian and Hellenistic cosmology, linked it to pre-exilic prophecy and designed a new understanding of history. However, there is no parallelism between Persian and Greek ideas of history which influenced apocalypticism.

Persian thinking was ethico-religious without definite cosmology. Greek thoughts especially the pre-Socratic developed after Hesiod the beginnings of our 'science world'. Thus we see Parmenides (515-445 BCE) introducing his scientific observations with a cosmic journey to heaven, a motif that became very important in apocalypticism. Admittedly, the high Greek literature ignored the apocalyptic meaning of history expressed by the Jews. They were so full of the cultural ruling knowledge and thought that outside Greek civilization only chaotic barbarism reigned. The Jews and Christians on the other hand with their theoretical monotheism faced this Hellenistic challenge with their apocalyptic view that God will surely triumph and reign at the end. They emphasized the imminent end of the world and the last judgment.

It must however be noted that the author of the book of Revelation like other New Testament authors writes from a perspective of faith that Jesus was the Messiah, exalted as Lord. Meier (1994), Chilton (1994) and Borg (1994) all share this view and devoted enormous literature on this problem. In Judaism, Messiah was an eschatological concept. They believed that the Messiah would appear at the end of the age to usher in a political system more favorable to the Jews than the one under which they 
lived. When early-Christians identified Jesus as the Messiah, they were not only tried to explain the personality of Jesus but also about the time in which they lived. They were convinced that they were living in the last days before the dawn of the new age. The new age would begin with the parousia on 'the day of the Lord'. The Hebrew bible interpreted the 'day of the Lord' to mean the day when Yahweh would come from heaven to punish Israel's enemies. Seeing Jesus as the Messiah, the early Christians transferred that coming from Yahweh to Jesus (Mark 13,24-26; 1 Thes $5,1-5$; 2Thes $1,5-10 ; 2,1-12)$. They prayed for it to happen soon with the Aramaic phrase "maranatha" meaning "Lord, come" (1Cor 16,22).

\section{Social Setting and Purpose of the Book of Revelation}

The book of Revelation like other apocalyptic works is an offshoot of a hope for the future nursed by a contingent of people who are dissatisfied with the present world. They looked forward to a divine intervention to bring about a more satisfactory world. The dissatisfaction arose during the time of persecutions by the Roman Empire. The Christians were dissatisfied with Rome who not only made no separation between the Religion and the State but also persecuted Christians. Rome promoted state religion including Emperor cult. All were expected to participate in it. The Jews were exempted because of the Romans' recognition of their adherence to ancient monotheistic religion. The Christians on the other hand received no such exemption. In the words of Dormeyer (1998):

Christianity and Judaism were seen as closely related due to their historical dependency and common writings. Religiopolitically speaking, at the turn of the century or maybe even earlier from the persecutions under Nero, Christianity separated off as a new religion. It was made a religioillicita and deprived of the 
monotheistic privilege enjoyed solely by Judaism under Rome, as is documented in the exchange of letters between the governor in Asia Minor, Pliny the Younger, and the Emperor Trajan. (p. 40)

Their refusal to practice the state religion was seen as unpatriotism, atheism and arrogance. They on their part saw the state religion as opposed to their faith in Christ. Conflict between the two therefore was inevitable. It is within this setting that the author of the book of Revelation wrote. He focused on the future to encourage people suffering unjustly in the present with the assurance of the intervention of the divine. It gives them hope by predicting that good would eventually triumph over evil. The author is convinced that God is sovereign and would surely punish the unjust and reward the good. The author marries symbolic images with his theme that the sufferings and persecutions are all preludes to the return of Christ for final judgment and creation of a new earth. His purpose was simply to correct the churches, encourage and exhort them. In the words of Marxsen (1976):

Properly understood, therefore, the author does not seek to encourage us to indulge in fanciful speculations; his aim rather is soberly to kindle into new life the hope that is growing faint under the oppression of the forces of the State - without extenuating or denying in any way the present distress that is still to come - and at the same time to issue a call to loyalty and perseverance. (p.276)

\section{Divine Sovereignty in the Book of Revelation}

Divine Sovereignty as evident in the chapters of the book of Revelation

The author of the book of Revelation convinces his readers that God is sovereign as seen in the entire book and also in the terms or attributes adopted for God. This paper deals firstly with the divine 
sovereignty as seen in the narratives of the book of Revelation. This will be followed by a brief look at the terms or attributes used of God in the book to express His sovereignty. Rohr and Martos (1988) talking on the sovereignty of God in the book of Revelation surmised that:

If we were to express the theme of the Apocalypse in a single sentence, it would be something like: steadfast faith in the midst of persecution is based on a sure hope of future glory. To say it yet another way: No matter how bad the conflict gets, good will triumph over evil at the end. Or to say it theologically: Even though Satan seems to be winning now, God's love and power will ultimately give the victory to Christ (p.156).

The Apocalypse is written in the midst of struggle. It is written to Christians who are experiencing struggle about the meaning and outcome of struggle. In the entire book, one see war being waged constantly between good and evil. Angels and dragons battle in heavens. Storms rage across the sky, stars fall and mountains are shattered. Wars and plagues and famines scorch the earth killing countless thousands. The entire cosmic drama simply symbolizes the worst happening and is yet to happen. Like Paul, the author believes that the body of Christ was being crucified in the world. It is clear to him that what happened to Christ is continuing in the incarnate Christ. He however represents the situation in a much more ancient and middle-eastern fashion using kaleidoscopic imagery. Just as Christ rose from the dead, so his body will rise to victory after all the deadly struggles. She will rise gloriously because of the sovereignty of her God. Rohr and Martos (1988) is convinced that John is much like the prophets of ancient Israel. Like them he beholds the past, present and future in a single flash 
of insight. He looks into the past and sees the pattern of God's action. He looks at the present and sees the same pattern at work. And he looks into the future and sees the divine pattern continuing. Then he speaks to the present with the conviction that what God did in the past is what He is doing and will continue to do. God is ever faithful to His promises and does not change. Christians need only to wait patiently to His sovereignty manifest at the end leading to their ultimate victory.

The author stylistically presents all the events taking place in the panorama of the world as though we are looking from heaven at the unfolding of a spectacular drama. He posits a perspective of eternity in a vision. It is as everything is predetermined with nothing to alter the cause of events. He sees the end of persecution and the ultimate triumph of God as surely as if it had already happened. Perkins (1978) observes that he author of the book of Revelation uses a style that pushes his listeners see everything from the perspective of heaven. It is filled with symbols of disjunction and separation. Since the listeners following the authors literary style see everything from heavenly perspective as if all is predetermined, they necessarily feel transported to those realms. Life belongs there. Continuing life on earth is unimportant. The real life is in heaven. One must not therefore be afraid of martyrdom. Perkins (1978) has two good graphic representation the functions within Revelation:

GOD $\longrightarrow$ JUDGMENT/SALVATION COMMUNITY/COSMOS

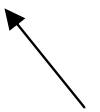

ANGEL/SEER CHRIST ANTI-DIVINE POWERS 


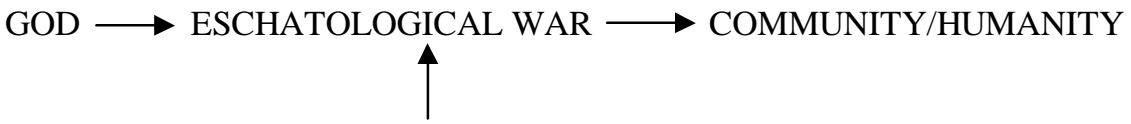

BABYLON/KINGS $\longrightarrow$ DRAGON - MICHAEL/CHRIST/MARTYRS OF EARTH/BEAST

The essence of seeing things as if decision is all done in heaven is not to make people relax to the inevitable but to inspire them to a courageous faith in God's power to conquer the forces of evil. Humanity is surrounded by storm of events. Man struggles to achieve happiness and peace. He works against terrific odds. Setbacks are encountered here and there. The author of Revelation in very attractive picturesque presents all these in a dramatic cosmic scale. He assures his audience that because the risen Christ is the Lord of history and because the power of the incarnate God is unconquerable the progress of humanity towards salvation is assured. Still it is not a human achievement. It is a divine gift base on God's sovereignty. An exposition of divine sovereignty in the book is better done through a section by section study following Fiorenza's division (Fiorenza 1981).

Divine Sovereignty is seen already in the first part of the book. Rev 1,1-8 commences with a lot of exultation and hope. The work begins with the opening words "ApokalupsisIēsouKristouhēnedōkenautō ho Theosdeixaitoisdouloisautou ha deigenesthai en takei" (Revelation of Jesus Christ which God gave him to show to his slaves what is necessary to be in speed). This immediately commands the hearers' attention to the fact that what he/she is about to read is not just any reading. It is a revelation from Jesus Christ. The medium of delivery "diatouaggelouautou" (through his angel) and the recipient "tōdoulōautouIōannē" (to his slave John) clears doubt as to how and the authenticity of the message. The author creates an 
initial sense of consolation and positive expectation with the phrase "ho gar kairoseggus" (for the time is near) after he has declared blessedness for those who read and obey what is written. The book is therefore not an option but a must read for all believers. It is not just an ordinary writing. It is not a homily. It is a message from the beyond, Christ himself and delivered safely to through an angel to an apostle. It contains everything that must necessarily come to be in the shortest time.

As soon as he has disposed his readers, in v. 4 he came up with greetings to increase their sense of wellbeing. Reference is made to God's throne and the seven spirits that surround it to remind the readers that God's power is sovereign and ultimate. The author still underscores the sovereignty of the divine by proclaiming Christ as "ho martus, ho pistos, ho prōtokokostōnnekrōnkai ho arkōntōnbasileōntēsgēs"(the faithful witness, the firstborn of the dead and ruler of the kings of the earth). With this expression, the author invites the readers to look beyond the oppressive powers of this world to the power of God. Knowing God is the ruler will surely bring the readers into an ecstatic mood heightened by the doxology in v. 6, the scriptural allusion in v. 7 and description of God as the Alpha and Omega in v. 8. The sovereignty is climaxed in what Christ says about himself "ho ōnkai ho ēnkai ho erkomenos, ho pantokratōr" (the one who is and who was and who is coming, the almighty).

In the next section the sense of divine sovereignty still holds sway. In Rev 1,10-16 the account of the loud voice like thunder (fōnēnmegalēnhōssalpigos) and description of one like the Son of Man (homoionhuionanthrōpou) creates a sense of awe and reminds the hearers of Christ's divine status and cosmic power; a fact underscored by the obeisance done by the visionary as he falls at the feet of the awesome figure expressing man's unworthiness 
before the divine. The hearers are encouraged to persevere in their faith since the vision and messages given against the background of the awesome vision of Christ and the various references to Christ's eventual return bolster the appeal with the promise of eventual vindication.

It is important to note that Revelation does not begin with the image of Jesus as a slain Lamb. Even though the motif of Jesus as slain Lamb seated on a throne runs through the book especially from $\operatorname{Rev} 5,6-20, \mathrm{He}$ is primordially presented as the victorious martyr (Rev 1,18). He is the heavenly and glorious son of Man from Daniel 7. The author instils it in the listener to always remember and never forget that Jesus has triumphed over death. $\mathrm{He}$ is proclaimed the King of Kings and Lord of the Kings of the Earth $(\operatorname{Rev} 1,4)$. It is necessary to convince his audience that Jesus is king, for unless so, it would be impossible for them to endure such sufferings. In Rev 3,21 the allusion to Christ's exaltation and as one who conquers coupled with the reference to his throne reminds the audience of the ultimacy of the power he represents.

The notion of the divine sovereignty is even made more evident in $\operatorname{Rev} 4,1-9,21$. The vision of the open door in heaven together with the command of the heavenly voice, the four (4) living creatures at worship combined with the twenty-four (24) elders seated on the throne and casting their crowns before the central throne stretches the notion of divine sovereignty beyond human imagination as the audience is caught up in the ecstasy of worship, wonder and adoration. The mystery of the seven (7) seals in Rev 5,1 and the search for a worthy one to open the seals creates a moment of suspension until the believers' exultation is heightened when the conquering Lion of Judah is deemed worthy of the task. The opening of the sixth seal in Rev 6,12-17 signals the 
commencement of the eschatological woes that must precede God's ultimate sovereignty.

The interlude in Rev 10,1 and the thought that not everything regarding the end is revealed to John increases the audience's sense of awe in the presence of the divine. The promise of no more delay in Rev 10,6 reminds the readers that God is sovereign and ultimately in control. In Rev 11,15 the audience is caught up again in a description of heavenly worship beginning with a proclamation of Christ's rule. There is a vision in $\operatorname{Rev} 11,18$ following the proclamation that God would destroy those who destroy the earth (kaidiaftheiraitousdiaftheirountastēngēn) still asserting the superiority of God's sovereign power to that of the forces that seem to rule the world.

The vision of the great war in heaven in Rev 12; the rising of the horrible beast from the sea in Rev 13,1 coupled with the worship of the beast and the question in Rev 13,4 as to who is able to challenge the beast (Tis homoiostōthēriōkai tis dunataipoleumēsaimet'autou?) leave the audience with the feeling that no ordinary human being can match the power of the terrible beast. This brings to its highest level the feeling of the readers as to the awareness of the vulnerability of the believers to the power of the enemy. At this crucial point of feeling, the author comes in with a dramatic image of hope in Rev 14,1: The Lamb standing on Mount Zion with the redeemed (kaieidon, kaiidou to arnionestosepi

orosZiōnkaimet'autoekatontesserakontatessareskiliades). This signifies for the audience that God's power is ultimate and sovereign. They will immediately have the feeling that only God is greater than the beast and can truly destroy him.

God's sovereignty is felt again from Rev 15,1 when the seven angels receive the golden bowel of God's wrath and pour them on 
the earth. The throne of the beast gets submerged, Euphrates dries up to make way for the kings of the East followed by the fall and disintegration of the old Babylon (Rome). By Rev 18,19 what seemed indestructible has come to her downfall and what wallowed in wealth has seen her wealth laid waste. By Rev 18,20 we meet an irony. Those who mourned the fall of Babylon turned from mourning to a joyous proclamation of God's justice. God is praised as a just judge and cosmic regent. The announcement of the marriage feast of the Lamb in Rev 19,7-9 marks a proclamation of the joyous moment of eschatological consummation, the realization of God's rule. In Rev 19,10 the angel forbids John from worshipping him and so reminds believers that only God is worshipped, not Emperors and not kings.

Pregeant (1997) has a good representation of divine sovereignty as carefully expressed in Rev 19,11-16. The author assumes once again an earthly perspective and describes the opening of heaven. The vision of the rider on the white horse reminds the audience of Isa 11,4 and of similar figure in $\operatorname{Rev} 6,2$. The Hebrew text of Isa 11,4 speaks of "the rod of his mouth" with which he shall strike the earth. The Septuagint translation renders it as "the word of his mouth". In both texts, the effect is destructive. The Messiah is to smash the arrogance of sinners like a potter's jar; to shatter all their substance with an iron rod; to destroy the unlawful nations with the word of his mouth (Collins 1995). In the book of Revelation, it is clear to the readers that this time the rider is Christ. They will contrast his messianic rule with the conquest in which the earlier figure engaged. Christ's awesome appearance signifies his ultimate power. The blood on his robe reminds the audience that he conquered by submitting to death. He has his sword, the symbol of judgment on his mouth because he rules by his prophetic word. In this case, his "rod of iron" can only 
be seen as metaphor for justice. He is given the title "King of kings" to depict his regal authority set over against false powers that have seemed to rule the world. It must be noted that the violence of the messiah typically has a fantastic character. He was not expected to prevail by normal military means but by his divine power.

The showdown between the forces of good and evil symbolized in the gathering of the beast and kings against the rider in Rev 19,17-18 reached a climax with the immediate capture of the beast to illustrate Christ's superior power. The sovereignty is even emphasized with the binding of Satan in Rev 20,1-3 marking a definitive victory over the source of evil itself though for a time.

Rev 20,7-10 now describes a final showdown between Christ and Satan. The powers of evil represented by Ezekiel's God and Magog were defeated and cast into hell with Satan. The phrase "forever and ever" (aiōnastōnaiōnōn) depicts the finality of the defeat. This sense of finality if strengthened with the appearance of the dead from the sea, the last judgment, and the casting of Death and Hades into the eternal fire. The judgment is aimed at those who refuse to acknowledge the sovereignty of God and follow the beast.

Rev 21,6 with the words from the throne gives the sense that God is both the origin and destiny of human lives and creation. Thus in Rev 22,8-9 all are reminded again that all worship belongs to God alone. Collins (1998) observes that the author of the book of Revelation has utter rejection of the claims of the Roman Empire to power and authority. He is firm in his conviction that power and authority belongs to Christ, the King of kings and Lord of lords. He is alone is to be worshipped; neither the state nor the Emperor. Bauckham (1993) corroborates that in Revelation the 
Messiah/Son of Man is one who may be worshipped. He did not reject John's obeisance as the angels did in Rev 19,10; 22,8-9.

Divine sovereignty as seen in the attributes used of God

The author of Revelation's designation of God as sovereign is very overt in some of the attributes he uses of God. He is both transcendent and immanent. He is not only the wholly other, the Lord of history, Creator of all things, $\mathrm{He}$ is ever present to the world as a person who acts with full deliberation and control. As in the OT, the God of the book of Revelation is strong and mighty in battle. Although His home is in heaven, He exercises unlimited power everywhere with equal ease. His power extends over history itself. No matter how catastrophic the situation may be, any misfortune can be remedied and handles by His life-giving beneficent power. He may allow His own to suffer for some time but His power to save is utterly certain. The believers only need to be patient and faithful. A brief outline of some of these attributes bears out this view.

The author of the book of Revelation presents God as Omnipotent and Almighty. He talks of him as the Alpha and Omega. Rev 1,8 says: "Egōeimi to Alfa kai to ōmega, legeikurios ho theos, ho ōnkai ho erkomenos, ho pantokratōr." (I am the Alpha and Omega, says the Lord God, the one who is and who comes, the almighty). Similar appellations are written of God various chapters of the book $(4,8 ; 11,17 ; 15,3 ; 16,7 ; 16,14 ; 19,15 ; 21,22)$. after recounting the fall of Babylon in Rev 18, one sees a multitude in worship. In Rev 19,6 they talk of God as almighty, the one who reigns. Thus God not only has regal power. He is superior to all others. His superiority is underscored by His omnipotence. He is almighty. Everything is under His power. Etymologically, omnipotence is a combination of two Latin words omnis meaning 
"all" and potens meaning "power". Roxburgh (1967) explains omnipotence as indicating that God has dominion over all thins outside Himself, which $\mathrm{He}$ has brought into existence and which He holds in existence. His omnipotence according to Revelation is unlimited. Thus He is King ( $\operatorname{Rev} 15,3$ and 19,6). $\operatorname{Rev} 11,15 ; 15,3$ hold that God reigns forever. He wields authority and power as in $\operatorname{Rev} 11,17 ; 12,10$ and 19,6 . He is enrobed in majesty ( $\operatorname{Rev} 4,1-11)$.

\section{Evaluation and Conclusion}

The book of Revelation shows a complexity of the progression of eschatological events as one reads through the chapters. It has had many detractors through the times. Some scholars like Charles (1920) tried to arrange the book in the order of chronology of events. The fact is that the author is not concerned with a chronological history of upcoming events. Other scholars like Whitehead (1967) give a "Process" interpretation to the book of Revelation. In his exposition of what he calls barbaric elements in Christianity, he thought that the book of Revelation posits God as a despot. Lawrence (1932) interprets Revelation as the "Judas" in the New Testament, an envy of the strong and a hatred of civilization. Apart from these negative critics, many scholars have found the book as of inestimable value. Fiorenza (1981) weighs the book positively from the prism of liberation theology when she writes that:

Revelation's theology is not so much interested in describing the "reversal of fate", because of an unchristian resentment of civilization or of the city, as it is in spelling out hope and encouragement for those who struggle for economic survival and freedom from persecution and murder. (p. 173) 
This paper submits that the purpose of the author was to inspire hope and confidence in his readers. Pregeant (1998) very strongly documented that the author's appeal was not to the intellectual urge to calculate but to the deep-seated emotional needs of his readers. The emotional need was encouragement in the face of sufferings and apparent hopelessness. Faced with persecutions and seeming ostracisms the author feels the need to convince his audience that after rain comes sunshine.

They must know that God in history always permitted the worst to happen to His people before His intervention. But then, His apparent silence in the face of sufferings is for the good of His people. The end is always victorious for those who remain faithful. To achieve his end, the author drew from standard apocalyptic repertoire to develop multiple symbols shaped by his extensive literary sources. By using multiple symbols, he immersed the audience in imaginative portrayals of God's judgment on the one hand and the blessedness of the eschatological rule. God controls the course of history and ultimately exercises coercive power over the forces of evil in bringing them to final judgment. The author in the lines and pages of Revelation and also in the attributes used of God demonstrates Him to be all powerful. Crisis may rock. Persecution may destroy many. Lives may be lost but Divine Sovereignty remains indubitable.

Despite the closeness of the end of the world in the view of the author, the book of Revelation remains a secure foundation in the transmission of revelations. It continues in the same vein as the Old Testament wisdom literature like the book of Daniel in that it reads in the present stress the chance to see the creative activity and dealings in history of God's wisdom and to live according to the guidelines, even though the dangers of persecution. It emphasizes a strong hope in imminent rescue in the last judgment. 
There is radical rejection of the present and move to ethical dualism in which salvation is now only expected at the future last judgment (Dormeyer, 1998). God will eventually bring all to judgment as the Alpha and Omega, the sovereign King of kings and Lord of lords. The wrath of God is aimed at those who refuse to acknowledge the sovereignty of God and follow the beast.

\section{Dominic Obielosi}

Department of Religion and Human Relations

Nnamdi Azikiwe University Awka dobielosi@yahoo.com

\section{References}

Bauckham, R. (1993): The Climax of Prophecy: Studies on the Book of Revelation. Edinburgh: T \& T Clark.

Borg, M.J. (1994): Jesus in Contemporary Scholarship. Valley Forge: Trinity.

Charles, R.H. (1920): The Revelation of St. John. 2 volumes. Edinburgh: T. \& T. Clark

Chilton, B.D. and Evans, C.A. (1994): Studying the Historical Jesus: Evaluation of the State of Current Research. Leiden: Brill.

Collins, A.Y. (1984): Crisis and Carthasis. The Power of the Apocalypse. Philadelphia: Westminster Press.

Collins, J.J. (1987): The Apocalyptic Imagination. An Introduction to the Jewish Matrix of Christianity. New York: Crossroad. 
(1995): The Scepter and the Star. The Messiahs of the Dead Sea Scrolls and Other Ancient Literature. New York: Doubleday Publishers.

Derrida, J. (1985): Apokalypse. Graz/Wien: Böhlaus.

Dormeyer, D. (1998): The New Testament Among the Writings of Antiquity, R. Kosov trans. Sheffield: Sheffield Academic Press.

Fiorenza, E.S. (1981): Invitation to the Book of Revelation. A Commentary on the Apocalypse with Complete Text from the Jerusalem Bible. Garden City: Doubleday.

Hemer, C.J. (1989): The Letters to the Seven Churches of Asia in Their local Setting. Grand Rapids: William B. Eerdmans Publishing Company.

Kümmel, W.G. (1995): Introduction to the New Testament. London: SCM Press.

Lawrence, D.H. (1932): Apocalypse. New York: Viking Press.

Marxsen, W. (1976): Introduction to the New Testament. A Concise and Up-to-date Guide to the New Testament Literature and its Historical Setting. Philadelphia: Fortress Press.

Meier, J.P. (1994): A Marginal Jew: Rethinking the Historical Jesus. New York: Doubleday.

Minear, P.S. (1968): I Saw New Earth: An Introduction to the Visions of the Apocalypse. Washington, D.C.: Corpus Books.

Perkins, P. (1978): Reading the New Testament: An Introduction. New York: Paulist Press.

Pregeant, R. (1997): Engaging the New Testament. An Interdisciplinary Introduction. Minneapolis: Fortress Press.

Rohr, R. and Martos, J. (1988): The Great Themes of Scripture. New Testament. New York: St. Anthony's Press. 
Roxburgh, G. (1967): "Omnipotence" in New Catholic Encyclopedia. New York: McGraw-Hill Book Company.

Treu, U. (1989) : 'ChristlicheSibyllinen', in W. Schneelmelcher ed. Neutestamentliche Apokryphen. Tübingen: J.C.B. Mohr.

Vielhauer, P. (1975): Geschichter der urchristlichenLiteratur. New York: W. de Gruyter.

Whitehead, A.F. (1967): Adventures of Ideas. New York: The Free Press. 